\title{
Storm-related variation in the growth rate of otoliths of larval Atlantic menhaden Brevoortia tyrannus: a time series analysis of biological and physical variables and implications for larva growth and mortality
}

\author{
Gary L. Maillet， David M. Checkley, Jr \\ Department of Marine, Earth, and Atmospheric Sciences, Box 8208, North Carolina State University,
} Raleigh, North Carolina 27695-8208, USA

\begin{abstract}
Vertical mixing induced by storms is hypothesized to modify the spatial and temporal availability of food to fish larvae and thus influence their feeding and growth. We investigated the effects of storms on sagitta growth rates of 2 age classes ( 3 to $15 \mathrm{~d}$ and 16 to $50 \mathrm{~d}$, post-hatching) of larval Atlantic menhaden Brevoortia tyrannus during winter 1986 in Onslow Bay, North Carolina, USA. We tested the null hypothesis that sagitta growth rate of 3 to $15 \mathrm{~d}$ and 16 to $50 \mathrm{~d}$ old larvae is independent of the timing and intensity of storms by using transfer functions to investigate relationships among daily time series of sagitta growth rate and meteorological and oceanographic variables. Variation in sagitta increment width was greatest during the first 1 to 2 wk after hatching. Reduction in sagitta growth rate coincided with storms and corroborated laboratory results that growth increments are formed daily and stressful events are manifest in sagitta microstructure. Age-related trends in sagitta growth rate were observed for both age classes and were removed from the analysis by a standardization procedure. Fluctuation in sagitta growth rate for 3 to $15 \mathrm{~d}$ old larvae was inversely crosscorrelated with time series of wind speed. Fluctuation in sagitta growth rate for 16 to $50 \mathrm{~d}$ old larvae was inversely cross-correlated with time series of wind speed and heat flux. The pattern of crosscorrelations for 3 to $15 \mathrm{~d}$ old larvae indicated an immediate response of sagitta growth rate to periods of strong winds while sagitta growth rate in 16 to $50 \mathrm{~d}$ old larvae lagged strong winds and heat fluxes by 2 to $5 \mathrm{~d}$. Transfer function models incorporating wind speed and heat flux accounted for 40 to $54 \%$ of sagitta growth rate variation. Reduction in larval Atlantic menhaden growth rate during early life is consistent with the critical period concept and may be related to dispersion and aggregation mechanisms coupled to wind-induced vertical mixing and its effect on food concentration and availability.
\end{abstract}

\section{INTRODUCTION}

Vertical mixing caused by storms is hypothesized to modify the spatial and temporal availability of food to fish larvae and thus influence their feeding and growth. Previous studies of wind-induced mixing effects on fish larvae feeding environment indicate the potential significance of wind events. Storms or periods of intense upwelling were shown to be detri-

\footnotetext{
- Present address: Department of Oceanography, Dalhousie University, Halifax, Nova Scotia, Canada B3H 4J1
}

mental to larval northern anchovy Engraulis mordax by dispersing aggregations of food which usually persist under non-turbulent conditions ('stable ocean hypothesis'; Lasker 1975, 1978). Observation of the feeding environment of larval cod Gadus morhua and haddock Melanogrammus aeglefinus during and after periods of intense wind mixing indicated a lowered incidence of feeding (Tilseth \& Ellertsen 1984) and dispersion of aggregated larva prey (Lough 1984). The relation between wind speed and mortality rate of larval northern anchovy E. mordax over large spatial scales supported the predicted effects of 
increased mortality caused by short-term turbulent mixing induced by strong winds (Peterman \& Bradford 1987).

Although the initial effects of wind-induced mixing may be detrimental to feeding of fish larvae, other studies have shown benefits under certain meteorological and hydrographic conditions. Thus, plankters can be concentrated in patches due to their buoyancy and behavior (e.g. in Langmuir circulations; Owen 1980). Wind mixing may also entrain or upwell nutrients into the mixed layer and result in phytoplankton blooms (Therriault et al. 1978). Increased primary production in response to mixing would enhance secondary production and ultimately benefit fish larvae (Mullin et al. 1985, Checkley et al. 1988, Dagg 1988, Kiørboe et al. 1988, Incze et al. 1990). Small-scale turbulence induced by strong winds may also enhance the encounter rate between fish larvae and their prey (Rothschild \& Osborn 1988, Sundby \& Fossum 1990). Thus detrimental effects of mixing (i.e. dispersion of aggregated larva prey) may be balanced by beneficial effects (i.e. enhanced secondary production and encounter rates).

The primary spawning of Atlantic menhaden is during winter along the western boundary of the Gulf Stream and south of Cape Hatteras (USA) and coincides with a maximum in the frequency of synopticscale storms (Checkley et al. 1988). Earlier investigations have implicated cross-shelf transport mechanisms (Zonal Ekman Transport) in regulating recruitment of Atlantic menhaden (Nelson et al. 1977). Recent investigations have hypothesized meteorological and oceanographic events operating over smaller temporal scales (e.g. days) and processes other than Ekman transport in regulating survival and drift of Atlantic menhaden eggs and larvae (Checkley et al. 1988).

The majority of prior studies investigating storm effects on larval fish ecology have emphasized the importance of characterizing the abundance and vertical distribution patterns of larva prey (Lasker 1975, 1978, 1981a, Mullin et al. 1985, Checkley et al. 1988, Dagg 1988, Incze et al. 1990). Few studies have directly assessed fish larvae response to storm-induced changes in their habitat along appropriate time and space scales (Lasker 1981b, Checkley et al. 1988, Incze et al. 1990). The net outcome of a synoptic-scale event may depend not only on the direction of storm-induced changes in microzooplankton prey, but the age, size, and recent nutritional condition of larval fish (Simpson 1987, Wroblewski \& Richman 1987). The objective of our present study is to investigate the short-term (e.g. days) response in sagitta growth rate of Atlantic menhaden larvae to passage of winter storms.

In this study we examined the relation between average daily incremental growth in sagitta otoliths of larval Atlantic menhaden and meteorological and oceanographic variables. Laboratory studies showed that short-term starvation did not alter age/increment number and was reflected in sagitta growth rate (Maillet \& Checkley 1990). The meteorological and oceanographic variables examined in our study included barometric pressure, air temperature, sea temperature, wind speed and heat flux at the ocean surface. The biological and physical data are developed in the form of time series. Application of BoxJenkins transfer function models (Box \& Jenkins 1976, Jenkins 1979) is used to quantify the relationship between the sagitta growth rate of larval Atlantic menhaden and meteorological and oceanographic conditions. Specifically, we evaluated the null hypothesis that average incremental growth rate of sagitta increments of 3 to $15 \mathrm{~d}$ and 16 to $50 \mathrm{~d}$ old larvae does not depend on the timing and intensity of synoptic-scale storms. We also examined the influence of average growth rates of larvae, estimated from size-atage data, on the timing of metamorphosis and discuss the implications of observed variability in larva growth rates for recruitment of Atlantic menhaden.

\section{MATERIALS AND METHODS}

Sampling. The study was conducted from Onslow Bay, North Carolina, USA to the western edge of the Gulf Stream during 12 cruises on the RV 'Cape Hatteras' from January 15 to March 15, 1986 (Fig. 1). Our study was in collaboration with the Genesis of Atlantic Lows Experiment (GALE), a study of US East Coast storms (Checkley et al. 1988, Dirks et al. 1988). The sampling protocol is described in Checkley et al. (1988). Atlantic menhaden larvae were preserved immediately in $95 \%$ ethanol and the preservative was changed within $48 \mathrm{~h}$ of initial collection to maintain otoliths in optimal condition.

Otolith preparation and analysis. Atlantic menhaden larvae were sorted from plankton tows within 3 mo of the final cruise and placed in fresh $95 \%$ ethanol. Up to 30 larvae were selected at random from tows containing $>30$ individuals; otherwise all specimens were used in the analysis. The right sagitta was examined in this study. Prior to removal of the sagitta, each larva was measured for standard length (SL: tip of upper jaw to end of notochord) and other morphometric measurements (head length, HL: distance between tip of upper jaw to tip of cleithrum; and body depth, BD: height of body at anus, excluding fin folds) to the nearest $0.1 \mathrm{~mm}$ with a stereomicroscope. The right sagitta was located with the use of polarized light (otoliths are birefringent), dissected out with a Minuten needle, and prepared according to methods 


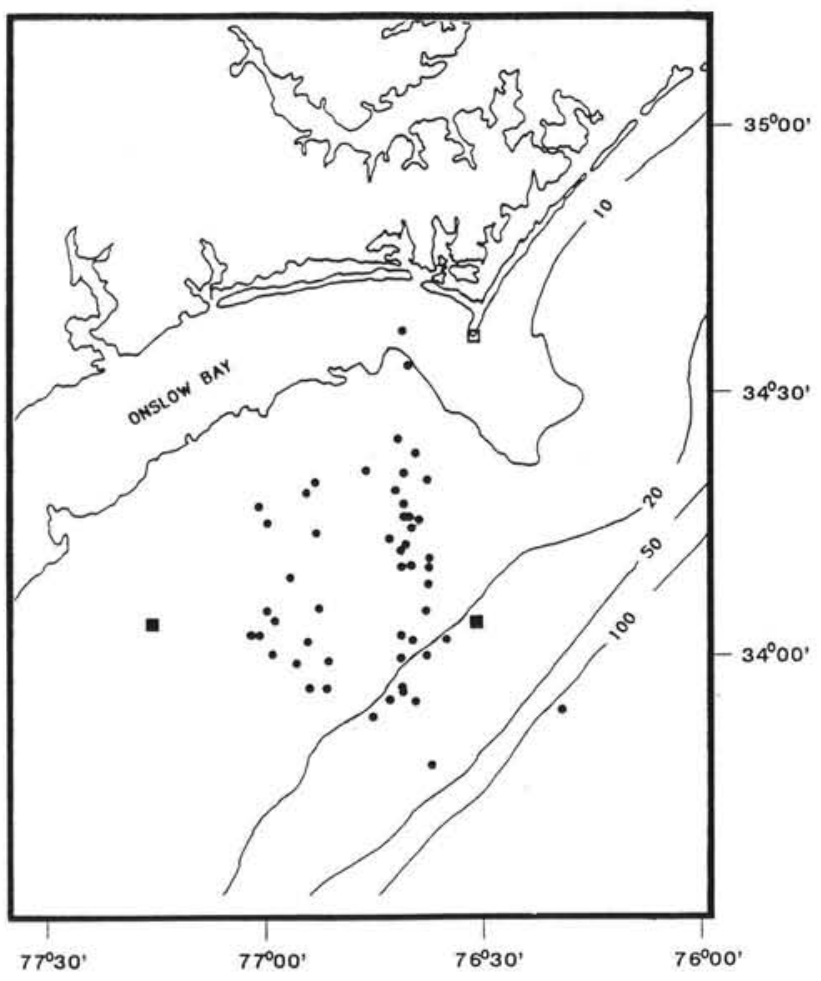

Fig. 1. Locations off North Carolina, USA, of sampling for Atlantic menhaden larvae $(\bullet)$, and meteorological instrument sites: (m) instrumented buoys; (ㅁ) coastal meteorological tower (Cape Lookout). Contour lines indicate bottom depth in fathoms $(1$ fathom $=1.83 \mathrm{~m})$

outlined in Maillet \& Checkley (1990). Sagitta increments, consisting of incremental and discontinuous zones (terminology of Mugiya et al. 1981), were counted with a compound microscope at a magnification of $1000 \times$ under bright field illumination. The condenser lens was lowered to increase contrast between incremental and discontinuous zones. Increment counts were obtained on blind (i.e. of unknown origin) samples on 2 separate occasions. Counts of increments were averaged if they did not differ by $>3$ increments, otherwise the specimen was excluded from further analysis. Six percent of the specimens were excluded due to variable increment counts. The average age ( $\mathrm{d}$ post-hatching) of larvae excluded was $18.8 \pm 6.5(\bar{x} \pm \mathrm{SD}$, range 8 to $50 \mathrm{~d})$. An additional $5 \%$ of the specimens was excluded due to preparation problems. The average size (SL) of larvae excluded was $10.2 \pm 2.5 \mathrm{~mm}$ (range 3.7 to 13.5 ). Repeated increment counts from each sagitta indicated that $92 \%$ of individuals were aged within \pm 1 increment.

Increment width measurements were obtained by displaying otolith images on a video monitor. Video increased total magnification (i.e. image size/otolith size) to $3600 \times$. The theoretical resolution of our microscope system was $0.24 \mu \mathrm{m}$ and was calculated according to Campana et al. 1987. An electronic caliper was used to measure increment width along the maximal radius to the nearest $0.1 \pm 0.2 \mu \mathrm{m}$, consistently the best line for enumerating increments. To facilitate increment width measurement, sagitta radius (SR: the distance from the center of the nucleus to the outer edge of each 3rd growth increment $\left(\mathrm{SR}_{i}\right.$, $i=0,3,6, \ldots$ ) moving inward from the periphery (i.e. capture date)) was recorded for each specimen. The focal plane was adjusted, if necessary, for the measurement of each 3rd increment. We chose to measure groups of 3 increments to allow a necessary, large number of larvae to be analyzed for time series analysis. Live standard length (SL) and dry weight (DW) were estimated from morphometric measurements of preserved specimens using the following equations:

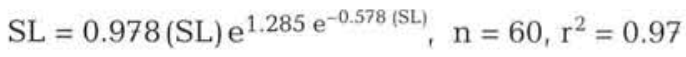

$$
\begin{aligned}
& \mathrm{DW}=6.552+1.211 \ln (\mathrm{HL})+1.751 \ln (\mathrm{BD}), \\
& \mathrm{n}=82, \mathrm{r}^{2}=0.97
\end{aligned}
$$

Eqs. (1) \& (2) were derived by measuring laboratoryreared larvae before and after net and fixative treatments similiar to those experienced by larvae collected in nature (Checkley et al. unpubl.).

The relationships of standard length and dry weight to sagitta radius were also investigated. Dry weight was measured after drying at $60{ }^{\circ} \mathrm{C}$ for at least $24 \mathrm{~h}$ (Checkley et al. unpubl.). Sagitta radius was measured from the center of the nucleus to the perimeter along the maximal radius. Linear and nonlinear regressions of standard length and dry weight on sagitta radius were computed using the GLM and NLIN procedures in the Statistical Analysis System (SAS 1984).

Growth estimates. The average growth rate $\left(\mathrm{mm} \mathrm{d}^{-1}\right)$ was computed for each larva by:

$$
\text { Average growth rate }=(\mathrm{SL}-3.6) / \text { Age }
$$

where SL $=$ size $(\mathrm{mm})$ at capture (corrected for collection and fixative effects); $3.6=$ average standard length (mm) at hatching (Powell \& Phonlor 1986, Maillet \& Checkley 1990), and age = days post-hatching (estimated from increment counts). The time to metamorphosis of Atlantic menhaden was computed as follows:

Time to metamorphosis $=$

$$
\frac{\text { Size at metamorphosis }-3.6}{\text { Average growth rate }}
$$

where size at metamorphosis is assumed to vary between 27 to $33 \mathrm{~mm}$, the range in SL at metamorphosis 
observed for Atlantic menhaden in laboratory and field studies (Lewis et al. 1972). Metamorphosis from larva to the juvenile life stage in Brevoortia spp, as well as other clupeiformes is defined as the time of forward movement of the dorsal fin and compression of the body (Fahay 1983, Hettler 1984). Age-specific growth rates of larvae collected and pooled from all cruises was described by the Laird-Gompertz growth model (Zweifel \& Lasker 1976) fitted to SL and estimated age by:

$$
\mathrm{SL}_{t}=\mathrm{SL}_{0} \mathrm{e}^{A_{0} / \alpha\left[1-\mathrm{e}^{-\alpha t}\right]}
$$

where $\mathrm{SL}_{t}=\mathrm{SL}$ at time $t_{i} \mathrm{SL}_{0}=\mathrm{SL}$ at hatching; $A_{0}=$ specific growth rate at hatching; $\alpha=$ rate of exponential decay of specific growth rate, and $t=$ age in days after hatching. The parameters $\mathrm{SL}_{0}, A_{0}$, and $\alpha$ were estimated from nonlinear regression of size on age using the NLIN procedure in the Statistical Analysis System (SAS 1984).

Dependent time series - sagitta growth rate. Specific growth rate (SGR) of sagitta was estimated for each larva during successive $3 \mathrm{~d}$ age intervals by:

$$
\mathrm{SGR}_{i}=\ln \left(\mathrm{SR}_{i} / \mathrm{SR}_{i+3}\right) / 3
$$

Two daily time series of SGR were constructed by grouping SGR estimates among all larvae. The first series consisted of SGR during 3 to $15 \mathrm{~d}$ of age (posthatching). The second series consisted of SGR for larvae aged 16 to $50 \mathrm{~d}$. These age classes were selected to investigate whether different larval age classes, and hence sizes, were affected differently by passage of storms. Evidence of an association between SGR and meteorological and oceanographic variables was initially evaluated using Spearman's rank (nonparametric) correlation statistic.

Independent time series - meteorological and oceanographic variables. Daily time series of barometric pressure (BP), air temperature (AT), water temperature (WT), wind speed (WS) and total heat flux (HF) were constructed from hourly values collected from a stationary, instrumented buoy in Onslow Bay $\left(34^{\circ} 10^{\prime} \mathrm{N}, 77^{\circ} 15^{\prime} \mathrm{W}\right.$, see Fig. 1). HF (sensible plus latent heat flux) was estimated using the iterative bulk aerodynamic method (Liu et al. 1979). A break in the time series occurred in late February due to battery failure. This time series was augumented using hourly data collected from a nearby buoy $\left(34^{\circ} 10^{\prime} \mathrm{N}, 76^{\circ} 30^{\prime} \mathrm{W}\right)$ and a coastal meteorological tower $\left(34^{\circ} 40^{\prime} \mathrm{N}, 76^{\circ} 30^{\prime} \mathrm{W}\right.$, see Fig. 1). Extension of the meteorological time series from data collected at the other instrument locations was justified based on the synoptic nature of the variables (Maillet 1988).
Time series analysis of dependent and independent series - transfer functions. Relationships between the dependent and independent series were evaluated by transfer functions (Box \& Jenkins 1976, Jenkins 1979) using the ARIMA (autoregressive-integrated-moving average) procedure in the Statistical Analysis System (SAS 1984, Brocklebank \& Dickey 1986). Transfer functions are a subclass of the Box-Jenkins ARIMA models and are capable of analyzing complex relationships among different time series. Transfer function application is useful when investigating the relation of a dependent series to single or multiple independent series, particularly when observations are not independent of each other (i.e. series exhibit autocorrelated behavior) and lag effects may be present.

Transfer functions incorporate the history of the dependent series and the current state and history of the related independent series. The general form of a transfer function is represented by:

$$
Y_{t}=U+\sum_{j=1}^{n} w_{j}(B) X_{j t}+[\Theta(B) / \phi(B)] a_{t}
$$

where $Y_{t}=$ the value of the dependent variable at time $t_{i i} U=$ a constant; $n=$ the number of variables; $w_{j}(B)=$ the transfer function weight for the $j$ th independent series (modeled as a ratio of moving-average to autoregressive terms); $B=$ the backshift operator denoting lag terms (e.g. $\left.B_{j} X_{t}=X_{t-j}\right) ; X_{j t}=$ the value of the $j$ th independent variable at time $t ; \Theta(B)=$ the moving-average polynomial of order $q_{i} \phi(B)=$ the autoregressive polynomial of order $p_{i}$ and $a_{t}=$ random noise at time $t$. In Eq. (7), the deviation in the dependent variable $\left(Y_{t}\right)$ from $U$ is represented as a linear function of current and past values of a single or combined independent series plus a noise term $\left(a_{t}\right)$. The general notation of an ARIMA model includes the parameters $p, d$, and $q$, sensu Box \& Jenkins (1976), where $p$ is the order of the autoregressive component, $d$ is the order of differencing required to remove nonstationarity, and $q$ is the order of the moving-average component. The ARIMA methodology is designed for stationary series whose basic statistical properties (e.g. means, variances, and covariances) remain constant over time (Box \& Jenkins 1976).

Our analysis of time series data using transfer functions involved several steps. The first step consisted of identifying and estimating univariate ARIMA models for the dependent and independent series. The maximum-likelihood estimation method was used in all analyses (SAS 1984). Univariate models for the meteorological and oceanographic variables were required in order to filter both the dependent and independent series before computing the cross-correlation function (CCF) at all lags, a pro- 
cess referred to as pre-whitening (sensu Box \& Jenkins 1976). Pre-whitening is necessary because of the potential for spurious cross-correlations when time series exhibit autocorrelated behavior. Univariate models for dependent time series also provide preliminary assessment of the noise model and a measure of residual variance in order to evaluate the introduction of the independent series in the transfer function model. The second step entailed identification and estimation of transfer function model parameters. The final step was diagnostic checking of the model's fit by examining the residuals. Examination of autocorrelation functions (ACF) and partial autocorrelation (PACF) of the series and pre-whitened CCFs were used to identify and estimate parameters of the transfer function model. Significant CCFs between the dependent and independent series provided evidence of an association between the biological and physical variables. Meteorological and oceanographic variables were included in the transfer function model if significant (based on $t$-statistics). The model was verified by examining residuals for departure from an uncorrelated sequence of random errors, referred to as white noise. If the residuals were not equivalent with white noise, a new model was identified and parameters estimated. The process was repeated until residuals appeared as white noise,

\section{RESULTS}

\section{Increment description and microstructure patterns.}

Larval sagitta increments were well-formed and exhibited high contrast under light microscopy (Fig. 2). Increment width ranged from 0.8 to $5.0 \mu \mathrm{m}$ (2.61 \pm 0.70 ) and was positively correlated with age at formation $(\mathrm{r}=0.47, \mathrm{p}<0.0001, \mathrm{n}=5982)$. More detailed examination of sagitta microstructure with SEM was not necessary based on the width of increments and resolution of our microscope system. Sagittae displayed a prominent growth increment surrounding the primordium, followed by 3 to 4 less-prominent increments (Fig. 2). This prominent increment was used as the starting point in age determinations. Remaining increments surrounding the nucleus were generally well-defined.

Variations in increment width were evident during larval growth history and occurred most often during the first 1 to $2 \mathrm{wk}$ after hatching (Fig. 3). Variation in sagitta increment width was often associated with passage of storms. The dates of growth disturbances, inferred from bands of narrow increments whose formation dates were estimated by counting increments back from the time of capture to the disturbance region, were closely related to the time of storm passage (Fig. 4).
Fig. 2, Brevoortia tyrannus. Light micrograph of right sagitta of a sea-caught Atlantic menhaden larva showing 34 growth increments which appear as alternate incremental (light) and discontinuous (dark) zones. The primordium (p) is defined as the innermost discontinuous zone (circular). The nucleus is defined as the area encompassed by the first continuous growth increment surrounding the primordium and is complete at hatching (h). The first prominent increment formed after hatching is formed at first feeding (ff). Scale bar $=10 \mu \mathrm{m}$

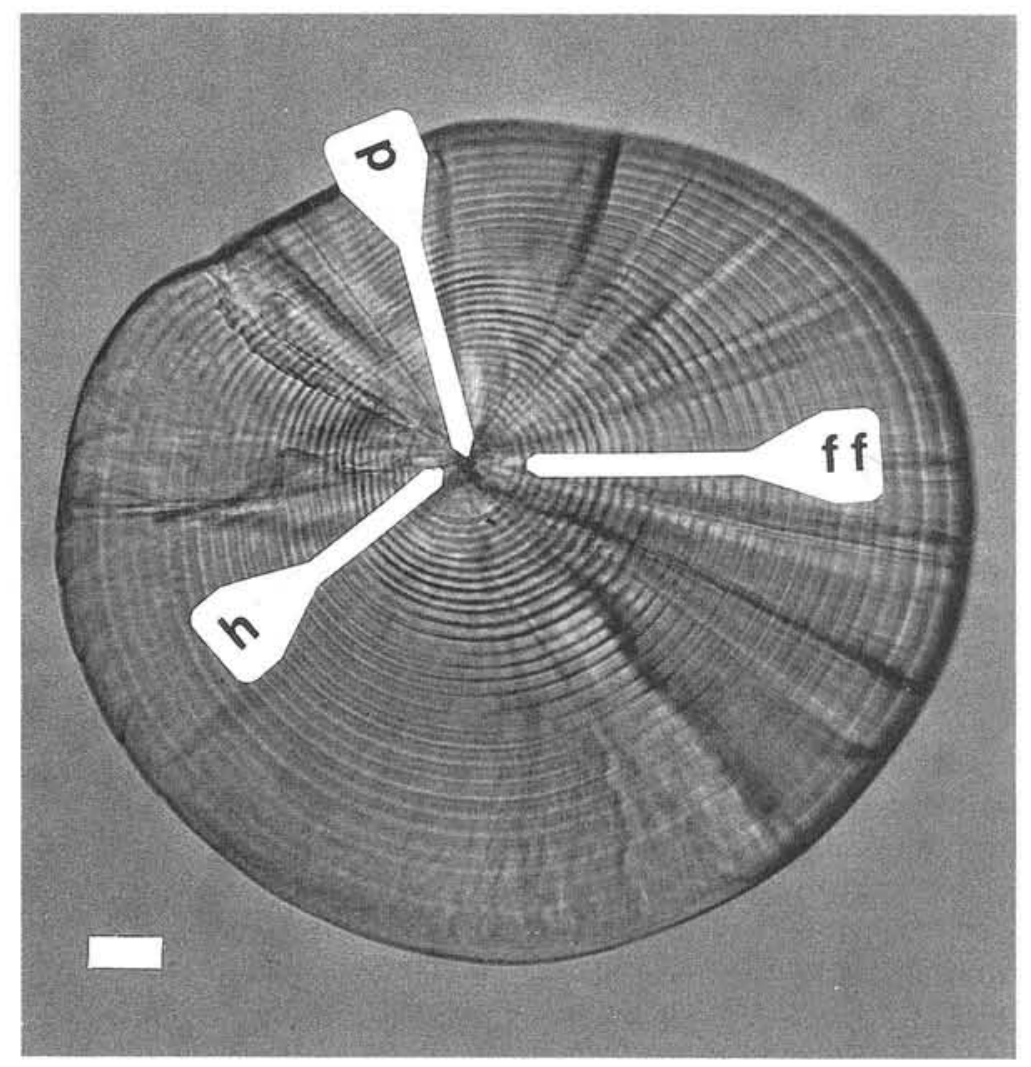




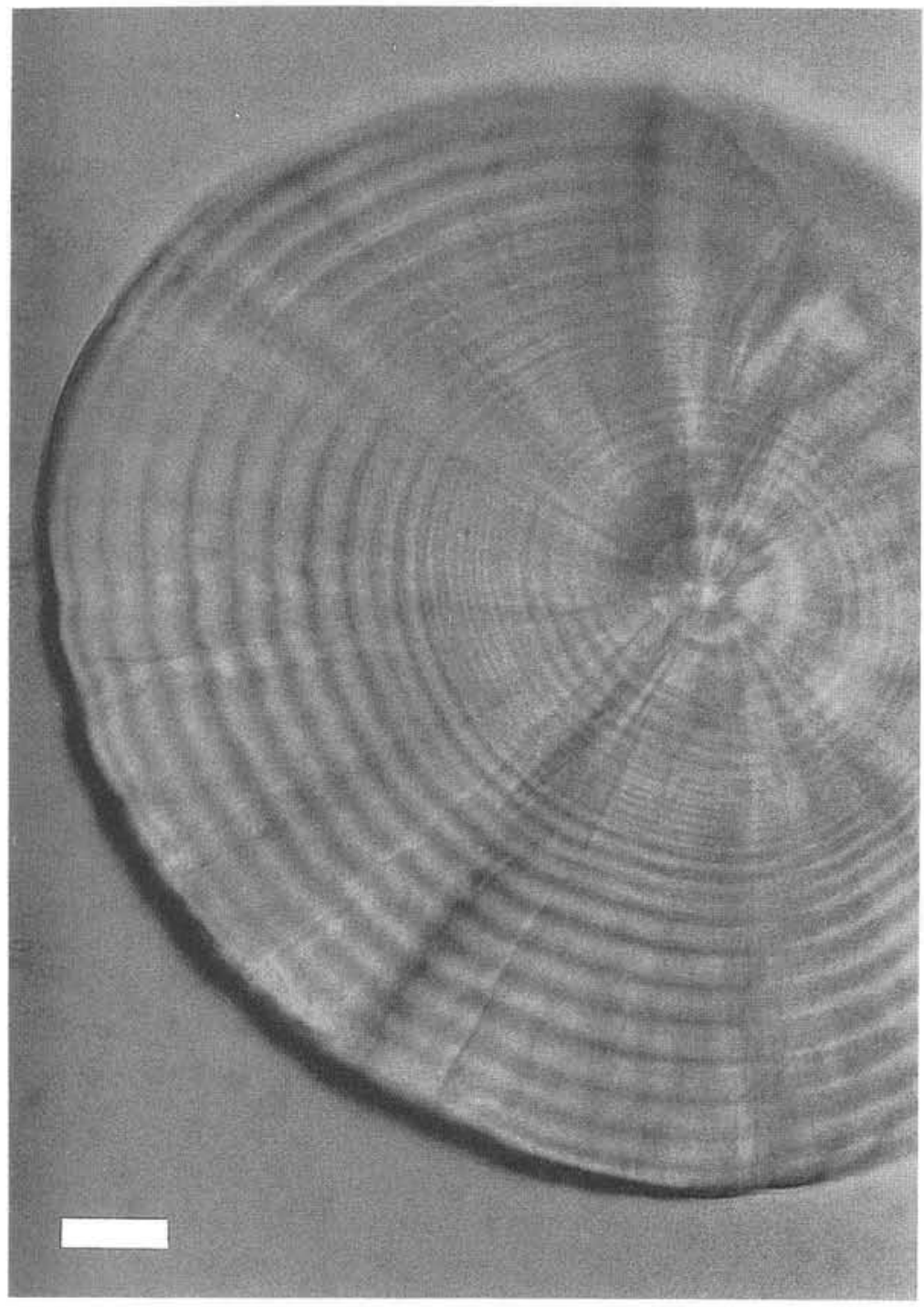

Fig. 3. Brevoortia tyrannus. Right sagittal otolith of Atlantic menhaden larva collected on February 14, 1986. Passage of a severe storm occurred on January 27 and was followed shortly by an intense cold air outbreak (air temperatures $<0^{\circ} \mathrm{C}$ ), strong winds $\left(>10 \mathrm{~m} \mathrm{~s}^{-1}\right.$ ) and large fluxes of heat from the sea surface $\left(>800 \mathrm{~W} \mathrm{~m}^{-2}\right.$ ). Storm conditions persisted for ca $48 \mathrm{~h}$. Region of narrow increments corresponds to storm passage (see also Fig. 4). Scale bar $=10 \mu \mathrm{m}$

\section{Age, size, and growth rate of larvae}

Larva age ranged from 9 to $50 \mathrm{~d}(\bar{x}=22.7 \pm 0.2 \mathrm{~d}$, $\mathrm{n}=1020$ ) and size ranged from 6.7 to $24.5 \mathrm{~mm}$ $(\bar{x}=14.6 \pm 0.1 \mathrm{~mm}, \mathrm{n}=1009$, corrected for collection and fixation effects). Larva size was inversely correlated with distance offshore and sea surface temperature at collection $(r=-0.46$ and -0.60 , respectively, $\mathrm{p}<0.0001, \mathrm{n}=1009$ ). Smaller, younger larvae were found predominately offshore near the western boundary of the Gulf Stream, defined here by the 19 to $21^{\circ} \mathrm{C}$ isotherms, while larger, older larvae were observed further inshore in cooler waters $\left(15\right.$ to $\left.17^{\circ} \mathrm{C}\right)$; see also Checkley et al. (1988).

Average growth rates of individual larvae computed from size-at-age data derived from otoliths varied nearly 3 -fold, from 0.25 to $0.66 \mathrm{~mm} \mathrm{~d}^{-1}(\bar{x}=$ $0.48 \pm 0.06)$, and was positively correlated with aver- age increment width $(\mathrm{r}=0.48, \mathrm{p}<0.0001, \mathrm{n}=1008)$. Maximal range for the larva period duration for Atlantic menhaden, estimated from our observed average growth rates and assumed range of size at metamorphosis of 27 to $33 \mathrm{~mm}$, was 35 to $118 \mathrm{~d}(\bar{x}=$ $55 \mathrm{~d}$, assuming size at metamorphosis of $30 \mathrm{~mm}$ and an average growth rate of $0.48 \mathrm{~mm} \mathrm{~d}^{-1}$ ).

The relationship between SL and age of larval Atlantic menhaden described by the Laird-Gompertz growth model (Fig. 5) was highly significant ( $<<$ 0.0001). Model parameters indicated a hatching size of $3 \mathrm{~mm} \mathrm{SL}$ and rate of exponential decay of specific growth rate of $0.06 \mathrm{~d}^{-1}$. Specific growth rates declined exponentially from $0.13 \mathrm{~d}^{-1}$ at hatching to $<0.01 \mathrm{~d}^{-1}$ at $50 \mathrm{~d}$ of age. Maximal absolute growth rate occurred at a size of $9.6 \mathrm{~mm}$ and age of $13 \mathrm{~d}$ SL and approached an upper asymptote of $24.6 \mathrm{~mm}$ at $50 \mathrm{~d}$ of age. 


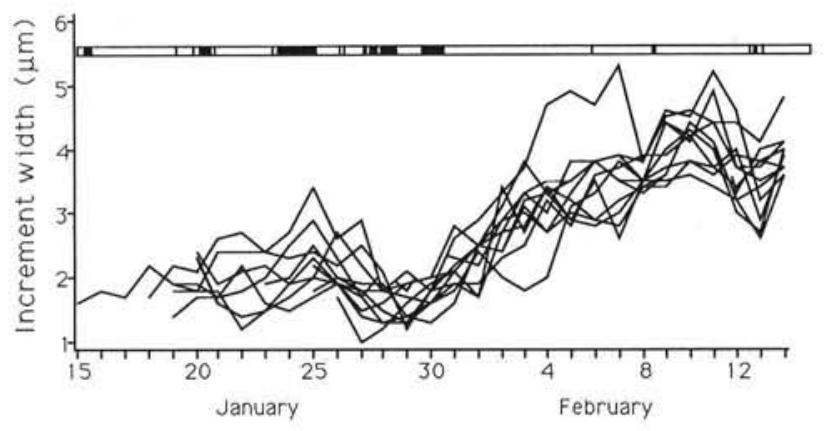

Fig. 4. Brevoortia tyrannus. Fluctuations in daily increment width in sagittal otoliths of representative Atlantic menhaden larvae collected at various stations on February 14, 1986. Darkened regions at top of figure correspond to periods when wind speeds exceeded $10 \mathrm{~m} \mathrm{~s}^{-1}$

\section{Sagitta size - larva size relation}

Relationships between standard length and dry weight to sagitta radius were described by nonlinear and linear regression models, respectively (Fig. 6). Both models were highly significant $(\mathrm{p}<0.0001)$. A curvilinear trend was apparent in the relation of standard length to sagitta radius and was fit with an asymptotic regression model. An exponential relationship between dry weight and sagitta radius was observed and thus the data were log-transformed to produce a simplified linear model.

\section{Dependent series - sagitta growth rate}

A total of 1020 sagitta otoliths were used to construct daily SGR time series during 3 to $15 \mathrm{~d}$ and 16 to $50 \mathrm{~d}$ of

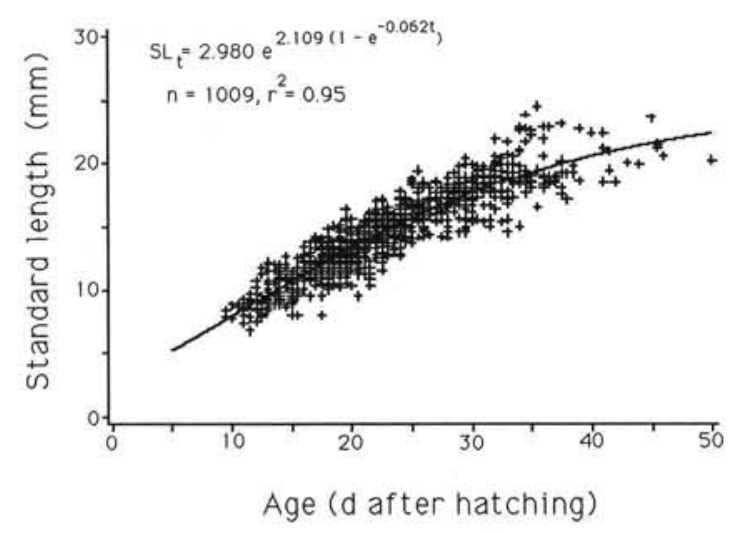

Fig. 5. Brevoortia tyrannus. Nonlinear regression (LairdGompertz growth model) of larva standard length (SL) on days after hatching for Atlantic menhaden. Model coefficients and other descriptive statistics are also given. Some symbols represent multiple observations. See text for explanation of equation
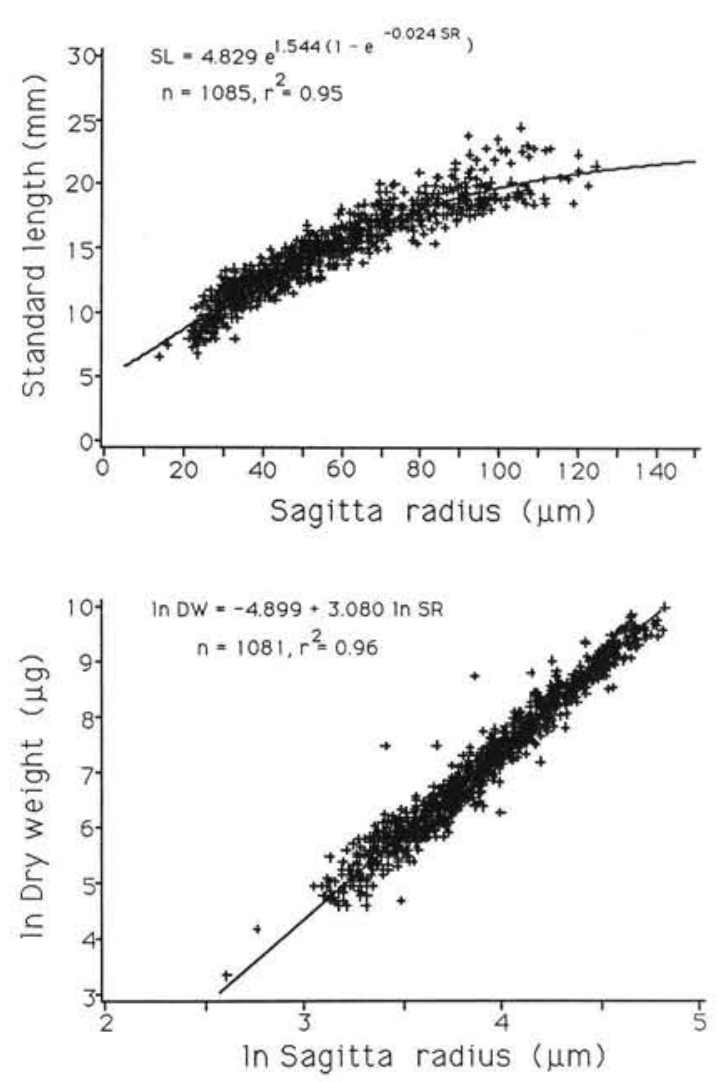

Fig. 6. Brevoortia tyrannus. Relation of larva standard length (SL) to maximal sagitta radius (SR) (upper), and ln dry weight (DW) to $\ln$ SR (lower) for larval Atlantic menhaden. Regression coefficients and other descriptive statistics are also provided. Some symbols represent multiple observations. See text for explanation of equations

age (Fig. 7). SGR during 3 to $15 \mathrm{~d}$ showed relatively large, cyclic fluctuations over the study period. SGR of this age class varied from 0.06 to $0.14 \mathrm{~d}^{-1}(\bar{x}=$ $0.097 \pm 0.020$ ). The corresponding time series for larvae during 16 to $50 \mathrm{~d}$ was characterized by smaller variations and periods of fast oscillation, particularly from late February through March (Fig. 7). SGR varied from 0.03 to $0.07 \mathrm{~d}^{-1}(\bar{x}=0.056 \pm 0.009)$.

Non-parametric correlations between SGR and meteorological and oceanographic variables provided evidence in support of negative effects of storms on larval Atlantic menhaden growth rate (Table 1). All correlations were significant ( $p<0.05$ ) except between WS and SGR 16 to $50 \mathrm{~d}(\mathrm{p}>0.05)$. BP and AT were positively related to SGR 3 to $15 \mathrm{~d}$ while WS and HF were negatively related. A similar pattern was observed during 16 to $50 \mathrm{~d}$ of age except that BP and SGR were negatively related and correlations were weaker compared to the 3 to $15 \mathrm{~d}$ age class.

SGR of both age classes was inversely correlated with age of larvae $(\mathrm{r}=-0.60, \mathrm{p}<0.0001, \mathrm{n}=3339$ for age 3 to $15 \mathrm{~d} ; \mathrm{r}=-0.60, \mathrm{p}<0.0001, \mathrm{n}=2643$ for age 


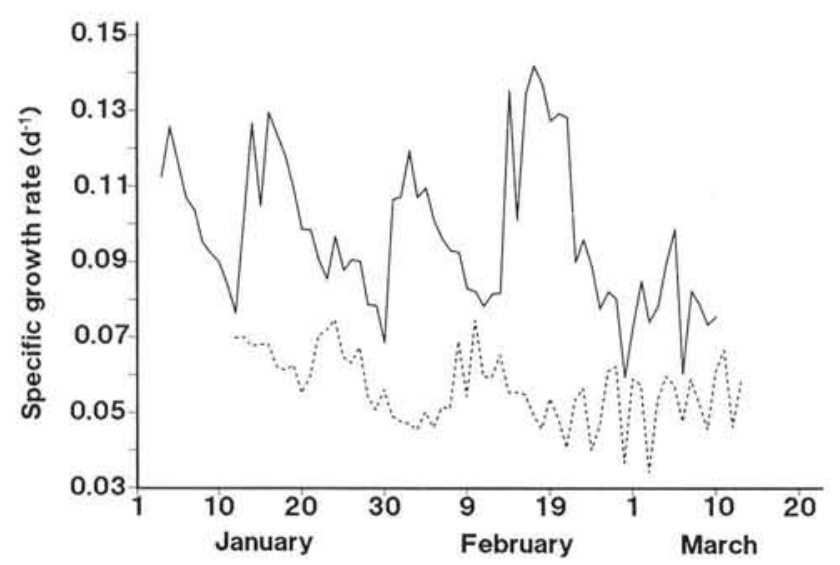

Fig. 7. Brevoortia tyrannus. Fluctuations in daily time series of specific sagitta growth rate of Atlantic menhaden larvae during 3 to $15 \mathrm{~d}(-)$ and 16 to $50 \mathrm{~d}(\cdots)$ of age (d posthatching) during winter 1986

16 to $50 \mathrm{~d}$ ), indicating that age-related growth trends contributed to variability observed in both series. The age-related trends in the series were removed by dividing the individual 3 d SGR estimate by its expected value using an empirical function derived from the combined estimates of specific growth rate for both age classes of larvae:

$$
\mathrm{SGR}=0.172 \mathrm{e}^{-0.055 t}, \quad \mathrm{r}^{2}=0.86, \mathrm{n}=5982
$$

where $t$ refers to time in days after hatching. The model indicated that SGR declined exponentially with larvae age. This procedure is referred to as standardization and has been used extensively to remove growth trends in ring-width series of trees (Fritts 1976, Cook 1987) but has not been commonly employed in the analysis of increment width in fish otoliths. The standardization procedure transforms the nonstationary time series to a new series of stationary indices. It is apparent from comparison of the SGR (Fig. 7) and SSGR (standardized SGR; Fig. 8) series that agerelated trends contributed significantly to the observed variability in SGR for both age classes.

Table 1. Spearman rank correlation coefficients ( $\mathrm{r}$ ) for specific sagitta growth rate (SGR) of larval Atlantic menhaden, aged 3 to $15 \mathrm{~d}(\mathrm{n}=3329)$ and 16 to $50 \mathrm{~d}(\mathrm{n}=2643)$, with barometric pressure (BP), air temperature (AT), wind speed (WS) and heat flux (HF). p: significance level

\begin{tabular}{|llllcc|}
\hline & & BP & AT & WS & HF \\
\hline SGR (3-15 d) & r & 0.042 & 0.293 & -0.260 & -0.275 \\
& p & 0.0144 & 0.0001 & 0.0001 & 0.0001 \\
SGR (16-50 d) & r & -0.097 & 0.131 & -0.034 & -0.114 \\
& p & 0.0001 & 0.0001 & 0.0832 & 0.0001 \\
\hline
\end{tabular}

Univariate ARIMA models fit to the dependent series were dominated by autoregressive (AR) processes (Table 2). The ACF for both dependent series displayed a damped sinusoidal decay pattern, characteristic of a stationary AR model. The PACF for the SSGR 3 to 15 d series exhibited a single significant lag value at $1 \mathrm{~d}$, suggesting a first-order AR model. The PACF exhibited significant lag values at $1,3, \& 4 \mathrm{~d}$ for the SSGR 16 to $50 \mathrm{~d}$ series suggesting a 4 th-order AR model. Significant values at lags of $1 \mathrm{~d}$, and 1, 3, \& $4 \mathrm{~d}$ indicate that current values of these series depend on values on Day 1, and Days 1, 3, \& 4 before. None of the ACFs of the residuals were significant $(p>0.05)$ indicating acceptable models for the dependent series. The percent variation in each of the dependent series that could be explained by the history of the series ranged from 38 to $43 \%$ (Table 2 ).

\section{Independent series - meteorological and oceanographic variables}

Fluctuations in the time series of meteorological and oceanographic variables were related to the passage of storms (Fig. 8). The dominant sequence of events during the study period included passage of several intense storms in late January accompanied by cold $\left(<0{ }^{\circ} \mathrm{C}\right)$, strong winds $\left(>10 \mathrm{~m} \mathrm{~s}^{-1}\right)$, and large fluxes of heat $\left(>800 \mathrm{~W} \mathrm{~m}^{-2}\right.$ ) from the sea surface. This period was followed by relative calm until passage of moderate storms in mid and late February and early March. The daily time series of sea surface temperature (SST) was not included in the time series analysis because it was not representative of the water temperatures experienced by all larvae, in contrast to the synoptic nature of the meteorological variables. However, SST does provide information about movements of water masses in the study region (Fig. 8). Thus, the peak period of storm activity in late January (27 to 29) coincided with a significant decline in water temperature from 16 to $13{ }^{\circ} \mathrm{C}$ at the buoy site, indicating displacement of the cooler, inshore water mass further offshore.

Univariate ARIMA models fit to the meteorological and oceanographic variables were characterized by moving-average (MA) processes except for wind speed (WS), which was a white noise series (Table 3 ). The dominance of MA processes indicated that current values depended to a greater degree on the past error (i.e. random movements) than on the past history of the series, consistent with the stochastic nature of weather variables. The independent series (BP, AT, and HF) exhibited a truncated pattern in the ACF with values dropping to zero after a $1 \mathrm{~d}$ lag, characteristic of a stationary MA model. Significant values for the PACF 

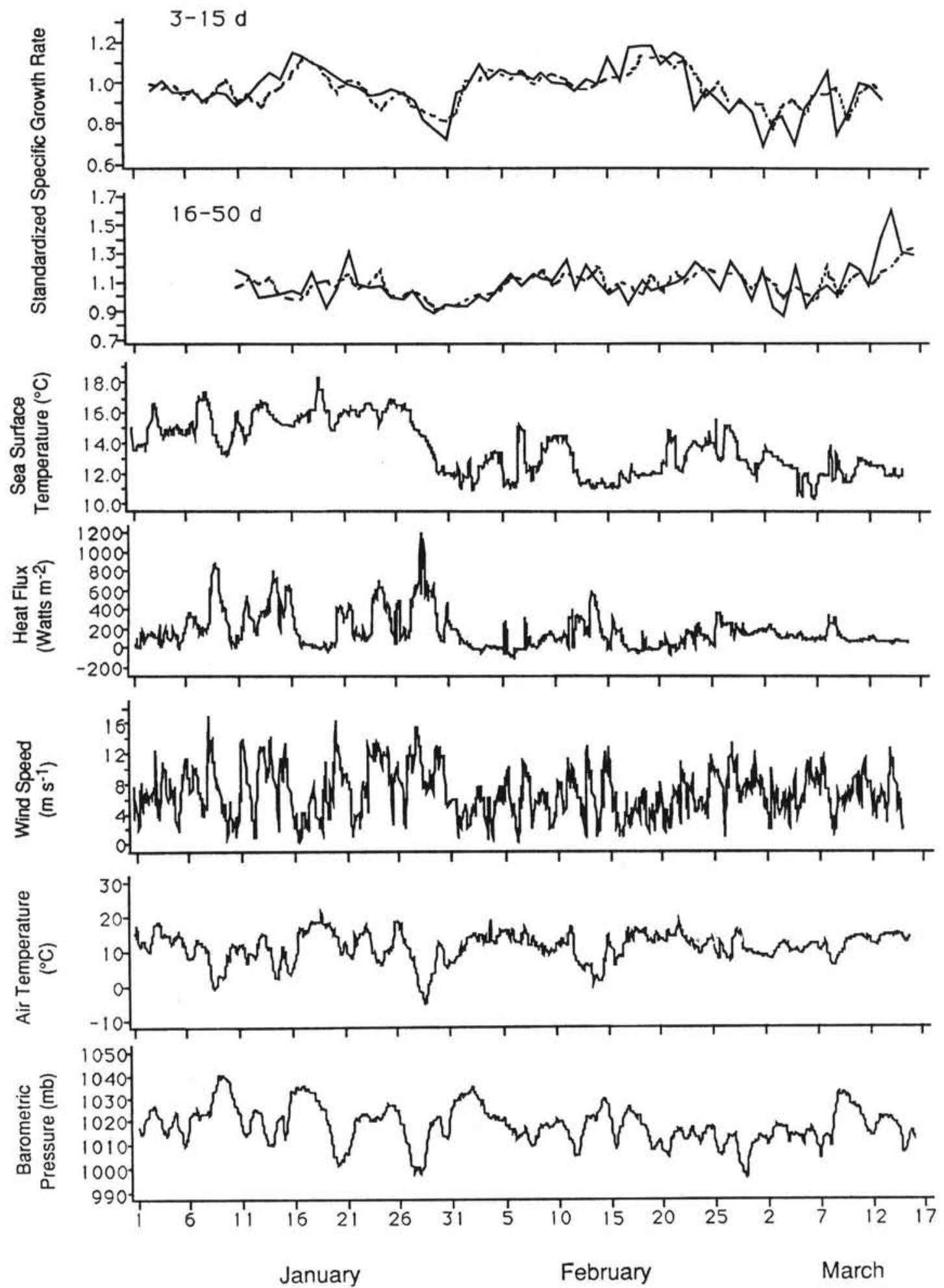

Fig. 8. Brevoortia tyrannus. Biological and physical time series. Upper 2 panels show daily time series of standardized specific sagitta growth rate (SSGR) for Atlantic menhaden larvae aged 3 to $15 \mathrm{~d}$ and 16 to $50 \mathrm{~d}$ post-hatching. Solid lines are observed values, broken lines correspond to values predicted from transfer function models. Lower 5 panels display the hourly time series of meteorological and oceanographic variables during winter 1986. See Fig. 1 for map of study site. Positive heat flux indicates 
Table 2. Summary of univariate ARIMA models estimated for the dependent time series ( $\left.Y_{t}\right)$; standardized specific growth rate (SSGR) of larval Atlantic menhaden aged 3 to $15 \mathrm{~d}$ and 16 to $50 \mathrm{~d}$. All parameter estimates are significant (p< 0.05 ). $p$ : order of autoregressive polynomial; $d$ : order of differencing; $q$ : order of autoregressive component; $B$; backshift operator; superscript $t$ : lag time; $a_{t}$ : error term at time $t_{i}$ and $r^{2}:\left(\mathrm{SS}_{\text {model }} / \mathrm{SS}_{\text {total }}\right)^{1 / 2}$

\begin{tabular}{|c|c|c|c|}
\hline $\begin{array}{c}\text { Adjusted } \\
\text { model } \\
(p, d, q)\end{array}$ & $\begin{array}{c}\text { Dependent } \\
\text { series } \\
Y_{t}\end{array}$ & $\begin{array}{l}\text { Estimated models and } \\
\text { standard errors }\end{array}$ & $r^{2}$ \\
\hline$(1,0,0)$ & $\begin{array}{c}\text { SSGR } \\
(3-15 \mathrm{~d})\end{array}$ & 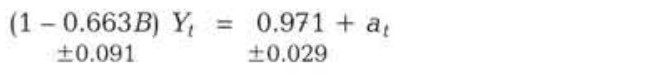 & 0.43 \\
\hline$(3,0,0)$ & $\begin{array}{c}\text { SSGR } \\
(16-50 \mathrm{~d})\end{array}$ & $\begin{array}{ccc}\left(1-0.466 B-0.510 B^{3}+0.373 B^{4}\right) Y_{t} & =1.095+a_{t} \\
\pm 0.114 \quad \pm 0.125 \quad \pm 0.149 & \pm 0.034\end{array}$ & 0.38 \\
\hline
\end{tabular}

at lags of 1 and $2 \mathrm{~d}$ for the BP and AT series indicated a second-order MA model. The PACF of the HF series displayed a significant lag at $1 \mathrm{~d}$ and was best fit with a mixed, first-order autoregressive-moving average model. None of the ACFs of the residuals were significant $(p>0.05)$ indicating acceptable models for the independent series.

\section{Transfer function models}

The CCFs of the pre-whitened series and residuals, obtained by fitting univariate ARIMA models to the independent and dependent series, were used to identify and estimate the order of the transfer function and noise component of the models. Parameters of the transfer function and noise terms were estimated simultaneously. Examination of the CCFs indicated that only WS was significantly cross-correlated with the SSGR 3 to $15 \mathrm{~d}$ series (Fig. 9). Parameters for the other independent series (BP, AT, and HF) were not significant $(p>0.05)$ and were removed from the model (Table 4). The SSGR 3 to $15 \mathrm{~d}$ series was significantly negatively cross-correlated $(r=-0.48, p$ $<0.0001, \mathrm{n}=68$ ) with WS. The CCF indicated that SSGR 3 to 15 d series responded immediately to changes in WS and also showed that periods of strong winds would continue to influence SSGR for several days after storm passage but this effect would diminish exponentially with time (Fig. 9). The final transfer function model accounted for $54 \%$ of the variation in the dependent series (Table 4).

Examination of the CCFs indicated that both WS and HF contributed in explaining variation in the SSGR 16 to 50 d series (Fig. 9). Parameters for the other independent series (BP and AT) were not significant $(p>0.05)$ and were removed from the model (Table 4). The SSGR 16 to $50 \mathrm{~d}$ series was negatively cross-correlated to WS and HF $(r=-0.30$ and $r=$ $-0.34, \mathrm{p}<0.01, \mathrm{n}=68$ ). The CCFs indicated that SSGR 16 to $50 \mathrm{~d}$ series lagged changes in WS by $4 \mathrm{~d}$ and HF by $2 \mathrm{~d}$, and WS also continued to influence the series for several days after the cessation of strong winds (Fig. 9). The final transfer function model accounted for $40 \%$ of the variation in the dependent series (Table 4).

Table 3. Summary of univariate ARIMA models estimated for the independent series $\left(X_{t}\right)$; of barometric pressure (BP), air temperature (AT), wind speed (WS) and heat flux (HF). All parameter estimates are significant $(\mathrm{p}<0.05)$. Symbols as in Table 2

\begin{tabular}{|c|c|c|c|}
\hline $\begin{array}{c}\text { Adjusted } \\
\text { model } \\
(p, d, q)\end{array}$ & $\begin{array}{c}\text { Independent } \\
\text { series } \\
X_{t}\end{array}$ & $\begin{array}{l}\text { Estimated models and } \\
\text { standard errors }\end{array}$ & $r^{2}$ \\
\hline$(0,0,2)$ & BP & $\begin{array}{c}X_{t}=1018.3+\left(1+0.736 B+0.334 B^{2}\right) a_{t} \\
\pm 1.5 \quad \pm 0.113 \quad \pm 0.114\end{array}$ & 0.36 \\
\hline$(0,0,2)$ & AT & $\begin{aligned} X_{t}= & 11.1+\left(1+0.773 B+0.185 B^{2}\right) a_{t} \\
& \pm 0.7 \quad \pm 0.119 \pm 0.118\end{aligned}$ & 0.35 \\
\hline$(0,0,0)$ & WS & $\begin{aligned} X_{t}= & 6.8+a_{t} \\
& \pm 0.3\end{aligned}$ & 0.01 \\
\hline$(1,0,1)$ & $\mathrm{HF}$ & 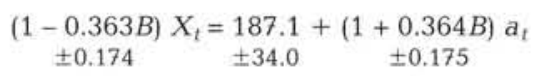 & 0.36 \\
\hline
\end{tabular}




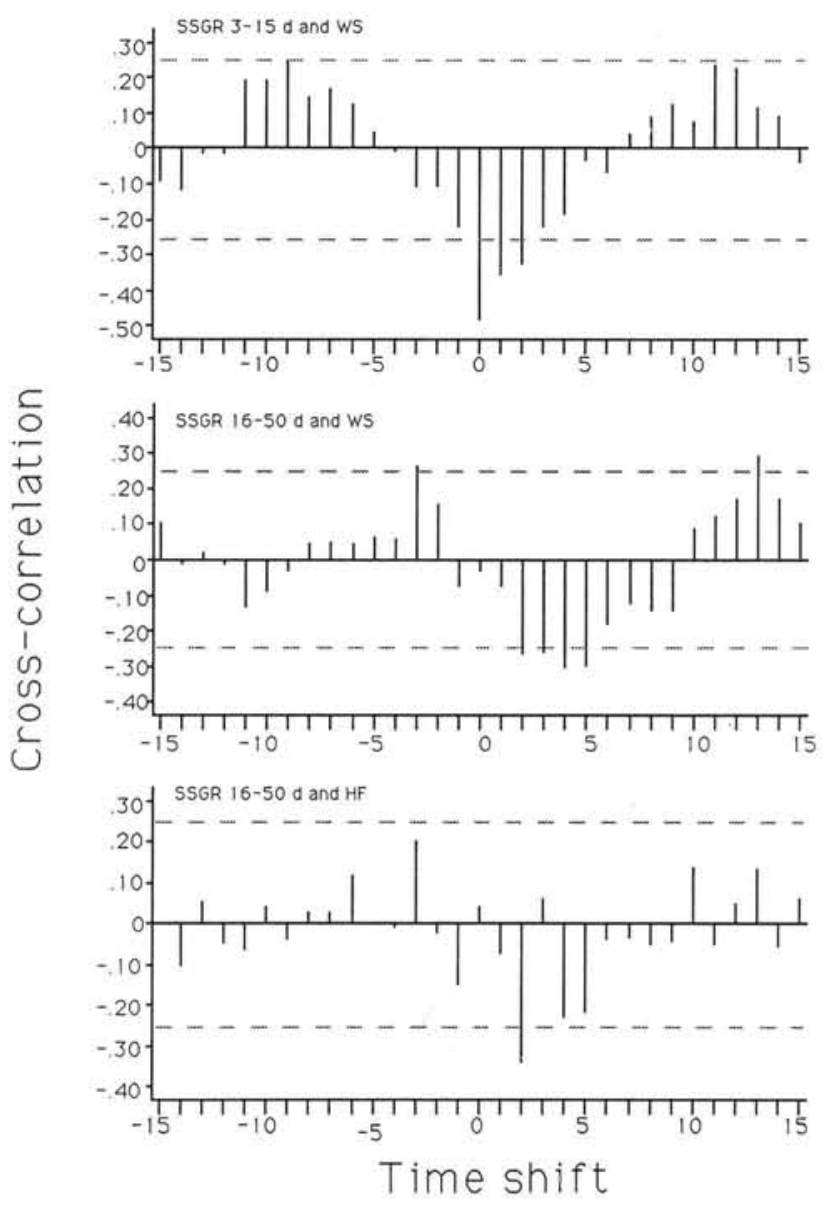

Fig. 9. Estimated cross-correlations (r, pre-whitened for the independent variables) between standardized specific sagitta growth rate (SSGR) of larvae aged 3 to $15 \mathrm{~d}$ and 16 to $50 \mathrm{~d}$ (post-hatching) and wind speed (WS) and heat flux (HF). Broken lines represent 2 standard error limits. Negative $(<0)$ time shifts indicate lead times in response of dependent variable to the independent variable while positive $(>0)$ time shifts indicate a lag period
Diagnostic checking of the transfer function models was accomplished by analysis of the residuals, which also provided information about the noise component (i.e. random error) of the model. The ACF and PACF of the SSGR 3 to $15 \mathrm{~d}$ series displayed a single significant $(\mathrm{p}<0.05)$ value at $1 \mathrm{~d}$ indicating a 1 st-order AR model for the noise term. The ACF and PACF of the SSGR 16 to $50 \mathrm{~d}$ series displayed significant $(\mathrm{p}<0.05)$ values at $1,3, \& 4 \mathrm{~d}$ indicating a 4 th-order AR model for the noise term. The residuals for both series were uncorrelated white noise and provided evidence in support of these AR noise models. The predicted values of the transfer function models were compared with observed values of SSGR for both age classes (Fig. 8).

\section{DISCUSSION}

The majority of larvae captured during the study period exhibited a characteristic pattern of increment formation. The nucleus consisted of a single primordium and was typically surrounded by a prominent increment. The first prominent increment is hypothesized to form at hatching. The 3 to 4 poorly defined increments immediately surrounding the first prominent increment approximate the estimated duration in days of yolk absorption at temperatures in the region of collection and probable spawning (Powell \& Phonlor 1986, Checkley et al. 1988). A second prominent increment was typically observed in sagitta after these poorly-defined increments and was related to the shift to exogenous feeding. This pattern of increment formation exhibited by larvae collected during our study is consistent with observations of known-age larvae reared in the laboratory (Maillet \& Checkley 1990). Formation of prominent increments (sometimes referred to as checks or discontinuities) has been observed in the otoliths of other species and appears to

Table 4. Summary of transfer function models fitted to the dependent time series $\left(Y_{t}\right)$; standardized specific growth rate (SSGR) of larval Atlantic menhaden aged 3 to $15 \mathrm{~d}$ and 16 to $50 \mathrm{~d}$, and independent series of wind speed (WS) and heat flux (HF). Subscripts for independent variables represent time lags (in d). All parameter estimates are significant ( $p<0.05$ ). Symbols as in Tables $2 \& 3$. See Fig. 7 to compare values observed with those predicted from the models

\begin{tabular}{|c|c|c|c|}
\hline $\begin{array}{c}\text { Adjusted } \\
\text { model } \\
(p, d, q)\end{array}$ & $\begin{array}{l}\text { Dependent } \\
\text { series }\end{array}$ & $\begin{array}{l}\text { Estimated models and } \\
\text { standard errors }\end{array}$ & $r^{2}$ \\
\hline$(1,0,0)$ & $\begin{array}{c}\text { SSGR } \\
(3-15 d)\end{array}$ & $\begin{array}{c}Y_{t}=1.260-0.016\left(1 /\left(1-0.626 B \mathrm{WS}_{t}\right)\right)+(1-0.571 B)^{-1} a_{t} \\
\pm 0.117 \pm 0.004 \quad \pm 0.147 \\
\pm 0.103\end{array}$ & 0.54 \\
\hline \multirow[t]{2}{*}{$(4,0,0)$} & $\begin{array}{c}\text { SSGR } \\
(16-50 \mathrm{~d})\end{array}$ & $\begin{array}{c}Y_{t}=1.319-0.007\left(1 /\left(1-0.739 B W \mathrm{WS}_{t-4}\right)\right) \\
\pm 0.211 \pm 0.005 \quad \pm 0.289\end{array}$ & 0.40 \\
\hline & & $\begin{array}{c}-0.00018 \mathrm{HF}_{t-2}\left(1-0.387 B-0.478 B^{3}+0.303 B^{4}\right)^{-1} a_{t} \\
\pm 0.00010 \quad \pm 0.123 \quad \pm 0.145 \quad \pm 0.184\end{array}$ & \\
\hline
\end{tabular}


be associated with behavioral and ecological transitions and/or periods of stress (Brothers \& McFarland 1981, Bailey \& Stehr 1988).

A close correspondence between the timing and intensity of winter storms and the timing and duration of growth disturbances, inferred by counting back from the date of capture to occurrences of narrow increments, supports the hypotheses that sagitta increments are formed daily and that storm-induced changes in the environment are manifest in sagitta microstructure of larval Atlantic menhaden. Laboratory studies investigating the effects of short-term ( 1 to $3 \mathrm{~d}$ ) starvation on sagitta microstructure of larval Atlantic menhaden indicated that age could be accurately estimated and changes in feeding coincided with a rapid decrease in increment width (Maillet \& Checkley 1990). Field and laboratory studies investigating the effects of different environmental factors on the microstructure of otoliths of other species have shown that variations in biotic (e.g. prey concentration and type) and abiotic (e.g. water temperature) factors induced detectable changes in increment width (Radtke 1984, Volk et al. 1984, Govoni et al. 1985, Gutierrez \& Morales-Nin 1986, Eckmann \& Rey 1987, Butler 1989).

Average growth rate of larval Atlantic menhaden aged 9 to $50 \mathrm{~d}$ was $0.48 \pm 0.06 \mathrm{~mm} \mathrm{~d}^{-1}$ for sea surface temperatures ranging from 15.0 to $20.2^{\circ} \mathrm{C}$. This rate is significantly greater than $0.32 \mathrm{~mm} \mathrm{~d}^{-1}\left(20^{\circ} \mathrm{C}\right)$ and $0.36 \pm 0.01 \mathrm{~mm} \mathrm{~d}^{-1}\left(19^{\circ} \mathrm{C}\right)$ for larvae reared in the laboratory (Powell \& Phonlor 1986, Maillet \& Checkley 1990). Our estimate of average growth rate for larval Atlantic menhaden was also significantly greater than estimates reported for other Brevoortia species. Average growth rate of larval Gulf menhaden collected in nature was $0.30 \mathrm{~mm} \mathrm{~d}^{-1}$ for sea temperatures ranging from 12.9 to $21^{\circ} \mathrm{C}$ (Warlen 1988). The observation that Atlantic menhaden larvae grow at significantly greater rates than Gulf menhaden over similar temperatures is consistent with results of an examination of early life history traits between these species (Powell \& Phonlor 1986). Average growth rate of larval Gulf menhaden was $0.30 \pm 0.03 \mathrm{~mm} \mathrm{~d}^{-1}$ reared at $20 \pm 2{ }^{\circ} \mathrm{C}$ and larval yellowfin menhaden $B$. smithi was $0.36 \mathrm{~mm} \mathrm{~d}^{-1}$ at $20^{\circ} \mathrm{C}$ and $0.45 \mathrm{~mm} \mathrm{~d}^{-1}$ at $26^{\circ} \mathrm{C}$ (Hettler 1984 and references cited therein).

The Laird-Gompertz growth model fitted to size-atage data for Atlantic menhaden accurately described population growth. Laird-Gompertz models fitted to size-at-age data are commonly employed to estimate age-specific growth rates of fish larvae, particularly when curvilinear trends are apparent (Zweifel \& Lasker 1976, Methot \& Kramer 1979). The upper asymptotic length of Atlantic menhaden larvae was $24.6 \mathrm{~mm} \mathrm{SL}$ and is near the observed length at which larvae begin transformation to the juvenile life stage
( 27 to $33 \mathrm{~mm} \mathrm{SL}$; estimated from Fig. 2 in Lewis et al. 1972). Our estimate of size at hatching of $3.0 \mathrm{~mm} \mathrm{SL}$ is slightly less than $3.6 \pm 0.2 \mathrm{~mm}$ SL for larvae reared at $19{ }^{\circ} \mathrm{C}$ (Maillet \& Checkley 1990). Our parameter estimates of asymptotic length, exponential decay of specific growth rate of $0.06 \mathrm{~d}^{-1}$, and age-specific growth rates ranging from 0.13 to $0.01 \mathrm{~d}^{-1}$ (hatching to $50 \mathrm{~d}$ of age) are similiar to estimates derived for a closely-related species, the Gulf menhaden, Brevoortia patronus (Warlen 1988). The asymptotic length of Gulf menhaden was $21.5 \mathrm{~mm} \mathrm{SL}$, exponential decay of specific growth rate was also $0.06 \mathrm{~d}^{-1}$, and age-specific growth rates varied from 0.07 to $<0.004 \mathrm{~d}^{-1}$ from age 10 to $60 \mathrm{~d}$ of age (post-fertilization).

Variations in sagitta growth rate observed for larval Atlantic menhaden may not be directly proportional to somatic growth rate. Thus, we restricted our analysis to estimation of sagitta growth rates instead of reconstructing somatic growth histories of individuals based on the relationship between sagitta and fish size (but see Campana 1990). Recent studies indicate that temperature and somatic growth rates can modify the relationship between otolith growth and somatic growth rate (Mosegaard et al. 1988, Secor \& Dean 1989, Wright et al. 1990). Although we have not yet demonstrated a direct relationship between somatic and sagitta growth rate at the daily level, our data indicate that sagitta growth rate is positively related to somatic growth rate. Reduction in increment width coincident with the timing and intensity of storms and we observed a highly significant relationship of length and weight of larvae to sagitta size. Also, short-term starvation (e.g. 1 to 3 d) was manifest in sagitta microstructure by reduction in increment width and was reflected in sagitta growth rate (Maillet \& Checkley 1990).

Implications of the observed variation in average growth rate of individual larvae was assessed by examining its influence on stage duration and survivorship. Average growth rate varied from 0.25 to $0.66 \mathrm{~mm} \mathrm{~d}^{-1}$ for larvae aged 9 to $50 \mathrm{~d}$ and indicated that individuals may reside in the larval stage for 35 to $118 \mathrm{~d}$ before metamorphosis. Although the number of studies are rather limited, size at metamorphosis has been shown to be less variable than age at metamorphosis among widely different fishes (Chambers \& Leggett 1987). The observed range in size at metamorphosis of Atlantic menhaden is also consistent with values of 0.05 for the coefficient of variation cited in Chambers \& Leggett (1987). A 2-fold variation in stage duration would result in a 70 -fold variation in survival, assuming a constant (e.g. $\left.0.1 \mathrm{~d}^{-1}\right)$ mortality rate. This factor would alone be sufficient to generate the observed variability in interannual recruitment of this species (Ahrenholz et al. 1987). A relationship between 
instantaneous growth and mortality rates of marine fish larvae has been postulated (Houde 1987, 1989) but little information is yet available to test this hypothesis for the majority of species. If a statistical relationship could be established linking growth and mortality rates for a particular species, information about interannual variation in growth rates of larva and juvenile stages could be used as an index of survivorship and recruitment success (but see Butler 1989, Owen et al. 1989).

Reduction in larva growth rate of Atlantic menhaden during early life is consistent with Hjort's (1914) critical period concept and modifications of it by others (reviewed by May 1974). Results of the time series analysis using transfer functions refute the null hypothesis that sagitta growth rate of larval Atlantic menhaden is not related to the timing and intensity of storms. Reduction in sagitta growth rate coincided with the passage of storms and the rate of decline was greatest among 3 to $15 \mathrm{~d}$ old larvae. Sagitta growth rate for 16 to $50 \mathrm{~d}$ old larvae showed less variability and appeared to be less influenced by these events. Growth histories derived from microstructural analysis of sagitta increments of larval redfish Sebastes spp. also indicated frequent reduction in growth rate during 10 to $15 \mathrm{~d}$ of age but not for older individuals (Penney \& Evans 1985). The difference between the 2 age classes observed in our study may be attributed to older, larger larvae being able to search greater volumes of water for available prey and having greater reserves, thereby enabling them to better endure unfavorable feeding conditions (Hunter 1981). Also, larger larvae may have more prey available to them within the same volume of water as compared to smaller larvae.

Transfer function models evaluated for the 2 age classes indicated that variations in sagitta growth rate among larvae aged 3 to $15 \mathrm{~d}$ were negatively correlated with fluctuations in wind speed while larvae aged 16 to $50 \mathrm{~d}$ were negatively correlated to both wind speed and heat flux. Fluctuations in the nonstandardized series of specific growth rate of sagitta depended on larva size and thus size difference must be accounted for before evaluating the influence of environmental variables on sagitta growth rate. We recommend that measurements of increment width first be standardized to remove age-related trends in growth before analysis of relationships between otolith growth and environmental variables. An appropriate model to remove age-related growth trends in otoliths, as in trees, is the negative exponential function. Such functions are likely to be species- and, perhaps, population-specific. Similiar findings were reported for larval Atlantic silversides Menidia menidia, in which the specific growth rate of sagitta was highly corre- lated with sagitta size and declined exponentially with age (Barkman \& Bengston 1987).

The negative effect of periods of strong winds on larva growth rate of Atlantic menhaden may be related to dispersion mechanisms and their effects on food concentration and availability. Our observations are consistent with Lasker's stability hypothesis, i.e. that vertical mixing induced by strong winds and/or periods of intense upwelling disperse or displace aggregations of plankton which are necessary for rapid growth and survival of marine fish larvae (Lasker 1975 , 1978). Similiar processes may also strongly affect the growth rate and, indirectly, survival of larval Atlantic menhaden, particularly during the first $2 \mathrm{wk}$ of life. The cross-correlations between sagitta growth rate of larvae aged 3 to $15 \mathrm{~d}$ and wind speed indicates that periods of strong winds coincided with an immediate reduction in sagitta growth rate and these events continued to negatively influence growth rate for several days after the cessation of strong winds. Sagitta growth rate of larvae aged 16 to $50 \mathrm{~d}$ lagged periods of strong winds by $2 \mathrm{~d}$ and also continued to negatively influence growth rate for several days after storm passage. Decrease in water temperatures coincident with storm passage may have also partly contributed to reduction in sagitta growth rate of larval Atlantic menhaden (Maillet 1988).

Time series of sagitta growth rate observed for larval Atlantic menhaden during our 2 mo field study lend general support to predictions made by a simulation model for larval northern anchovy in response to wind mixing events (Wroblewski et al. 1989). Periods of high winds associated with storm passage resulted in reduction of sagitta growth rate, consistent with the proposed dispersion mechanism and its effect on food concentration and larva growth rate. The month of January 1986 was characterized by intense storms and associated with significant decreases in sagitta growth rates, particularly for larvae aged 3 to $15 \mathrm{~d}$. Specific growth rates continued to decline for ca $2 \mathrm{wk}$ for young larvae before a rapid recovery in early February, associated with relatively calm seas. Similiar trends were observed in older individuals although variations were much smaller in magnitude. The rapid recovery of larval growth rates of aged 3 to $15 \mathrm{~d}$ in early February may have been related to the short response time of herbivorous zooplankton to enhanced primary productivity and to aggregation mechanisms, although we expected a more rapid recovery based on pre- and post-storm concentrations of microzooplankton observed in the study site (Checkley et al. 1988). Interestingly, a $2 \mathrm{wk}$ time period corresponds closely to the theoretical optimum in storm frequency estimated for larval northern anchovy in response to wind mixing events (Wroblewski et al. 1989). 


\section{CONCLUSIONS}

The importance of synoptic-scale storms and their effects on fish larva feeding and growth is supported by our field results. Variation in larva growth rate of Atlantic menhaden, inferred from microstructural analysis of sagitta increments, was strongly coupled to storm passage. Our results indicate that storm intensity, frequency, and duration during Atlantic menhaden spawning season are important determinants of larva growth rate, stage duration and, perhaps ultimately, recruitment success. Our results are consistent with mounting evidence for the direct role of physical processes in fish recruitment. Variations in the distribution, abundance, and production dynamics of fish and their prey and predator populations have been related to the influence of large-scale meteorological and hydrographic processes in the aquatic environment (Hayman \& Tyler 1980, Frank \& Leggett 1982, Leggett et al. 1984, Shepherd et al. 1984, Eckmann et al. 1988, Cury \& Roy 1989).

Time series methods, including transfer functions, and microstructural analysis of sagitta increments have not been previously combined, despite the oftstated need to reduce our scales of observation in order to better understand the processes affecting larval fish. Confirmation of daily growth increment formation in otoliths and the relation of otolith growth to larval fish growth provide a unique opportunity to gather information about the growth of individuals over biologically-relevant time scales. Such data would provide information about the generality of effect of meteorological and hydrographic processes on the growth and survival of the early life stages of fish. Hypotheses and tests concerning the importance of growth rate variability and the effect of environmental variation on survival and recruitment of fish may substantially benefit from pursuing this approach.

Acknowledgements. The efforts of G. N. Maillet, C. A. Miller, and R. Quinones in collection of samples at sea are greatly appreciated. The captain and crew of the RV 'Cape Hatteras' provided assistance on numerous occasions at sea. A. Akkarapuram and Drs A. Riordan and S. Raman provided help with acquistion and analysis of meteorological and oceanographic data. Drs D. A. Dickey and P. Bloomfield provided helpful discussions with time series and statistical analyses. We thank Drs D. A. Dickey, D. Kamykowski, S. M. Warlen, L. B. Crowder, and 3 anonymous reviewers for comments on the manuscript. This research was supported by grants from the National Science Foundation to D. M. Checkley, Jr (OCE-8516799, OCE-89-17257).

\section{LITERATURE CITED}

Ahrenholz, D. W., Nelson, W. R., Epperly, S. P. (1987). Population and fishery characteristics of Atlantic menhaden, Brevoortia tyrannus. Fish Bull. U.S. 85: 569-600

Bailey, K. M., Stehr, C. L. (1988). The effects of feeding periodicity and ration on the rate of increment formation in otoliths of larval walleye pollock Thergra chalcogramma. J. exp. mar. Biol. Ecol. 122: 147-161

Barkman, R. C., Bengtson, D. A. (1987). The record of daily growth in otoliths of Atlantic silversides, Menidia menidia, from field and laboratory. J. Fish. Biol. 31: 683-695

Box, G. E. P., Jenkins, G. M. (1976). Time series analysis, forecasting and control. Holden-Day, Inc., San Fransisco

Brocklebank, J. C., Dickey, D. A. (1986). SAS views: SAS system for forecasting time series. SAS Institute Inc., Cary, NC

Brothers, E. B., McFarland, W. N. (1981). Correlation between otolith microstructure, growth and life transitions in newly recruited French grunts (Haemulon flavolineatum). Rapp. P.-v. Réun. Cons. int. Explor. Mer 178: 369-374

Butler, J. L. (1989). Growth during the larval and juvenile stages of the northern anchovy, Engraulis mordax, in the California Current during 1980-84. Fish. Bull. U.S. 87 : 645-652

Campana, S. E. (1990). How reliable are growth backcalculations based on otoliths? Can J. Fish. Aquat. Sci. 47: 2219-2227

Campana, S. E., Gaga, J. A., Munro, J. (1987), Otolith microstructure of larval herring (Clupea harengus): image or reality? Can. J. Fish. Aquat. Sci. 44: 1922-1929

Chambers, R. C., Leggett, W. C. (1987). Size and age at metamorphosis in marine fishes: an anlysis of laboratory-reared winter flounder (Pseudopleuronectes americanus) with a review of variation in other species: Can. J. Fish. Aquat. Sci. 44: 1936-1947

Checkley, D. M. Jr, Raman, S., Maillet, G. L., Mason, K. M. (1988). Winter storm effects on the spawning and larval drift of a pelagic fish. Nature, Lond. 335: 346-348

Cook, E. R. (1987). The decomposition of tree-ring series for environmental studies. Tree-Ring Bull. 47: 37-59

Cury, P., Roy, C. (1989). Optimal environmental window and pelagic fish recruitment success in upwelling areas. Can. J. Fish. Aquat. Sci. 46: 670-680

Dagg, M. J. (1988). Physical and biolgical responses to the passage of a winter storm in the coastal and inner shelf waters of the northern Gulf of Mexico. Cont. Shelf Res. 8: $167-178$

Dirks, R. A., Kuettner, J. P., Moore. J. A. (1988) Genesis of Atlantic Lows Experiment (GALE): an overview. Bull. Am. met. Soc. 69: 148-160

Eckmann, R., Rey, P. (1987). Daily increments in the otoliths of larval and juvenile Coregonus spp., and their modification by environmental factors. Hydrobiologia 148: 137-143

Eckmann, R., Gaedke, U., Wetzlar, H. J. (1988). Effects of climatic and density-dependent factors on year-class strength of Coregonas lavaretus in Lake Constance. Can. J. Fish. Aquat. Sci. 45: 1088-1093

Fahay, M. P. (1983). Guide to the early stages of marine fishes occurring in the western North Atlantic Ocean, Cape Hatteras to the southern Scotian Shelf. J. NW Atl. Fish. Sci. $4: 1-423$

Frank, K. T., Leggett, W. C. (1982). Coastal water mass replacement: its effect on zooplankton dynamics and the predator-prey complex associated with larval capelin (Mallotus villosus). Can. J. Fish. Aquat. Sci. 39: 991-1103

Fritts, H. C. (1976). Tree rings and climate. Academic Press, London 
Govoni, J. J., Chester, A. J., Hoss, D. E., Ortner, P. B. (1985) An observation of eposidic feeding and growth of larval Leiostomus xanthurus in the northern Gulf of Mexico. J. Plankton Res. 7: 137-146

Gutierrez, E., Morales-Nin, B. (1986). Time series analysis of daily growth in Dicentrarchus labrax L. otoliths. J. exp. mar. Biol. Ecol. 103: 163-179

Hayman, R. A., Tyler, A. V. (1980). Environment and cohort strength of Dover sole and English sole. Trans. Am. Fish. Soc. 109: 54-70

Hettler, W. F. (1984). Description of eggs, larvae, and early juveniles of Gulf menhaden, Brevoortia patronus, and comparisons with Atlantic menhaden, B. tyrannus, and yellowfin menhaden, B. smithi. Fish. Bull. U.S. 82: 85-95

Hjort, J. (1914). Fluctuations in the great fisheries of northern Europe viewed in the light of biological research. Rapp. P.-v. Réun. Cons. perm. int. Explor. Mer 20: 1-228

Houde, E. D. (1987). Fish early life dynamics and recruitment variability. Am. Fish. Soc. Symp. 2: 17-29

Houde, E. D. (1989). Comparative growth, mortality, and energetics of marine fish larvae: temperature and implied latitudinal effects. Fish. Bull. U.S. 87: 471-495

Hunter, J. R. (1981). Feeding ecology and predation of fish larvae. In: Lasker, R. (ed.) Marine fish larvae: morphology, ecology and relation to fisheries. University of Washington Press, Seattle, p. 33-77

Incze, L. S., Ortner, P. B., Schumacher, J. D. (1990). Microzooplankton, vertical mixing and advection in a larval fish patch. J. Plankton Res. 12: 365-379

Jenkins, G. M. (1979). Practical experiences with modelling and forecasting time series. Gwilym Jenkins and Partners (overseas) Ltd., Channel Islands

Kiørboe, T. Munk, P., Richardson, K., Christensen, V., Paulsen, H. (1988). Plankton dynamics and larval herring growth, drift and survival in a frontal area. Mar. Ecol. Prog. Ser. 44: 205-219

Lasker, R. (1975). Field criteria for survival of anchovy larvae: the relation between inshore chlorophyll maximum layer and successful first feeding. Fish. Bull. U.S. 73: 453-462

Lasker, R. (1978). The relation between oceanographic conditions and larval anchovy food in the California Current: identification of factors contributing to recruitment failure. Rapp. P.-v. Réun. Cons. int. Explor. Mer 173: 212-230

Lasker, R. (1981a). Factors contributing to variable recruitment of the northern anchovy (Engraulis mordax) in the California Current: contrasting years, 1975 through 1978. Rapp. P.-v. Réun. Cons. int. Explor. Mer 178: 375-388

Lasker, R. (1981b). The role of a stable ocean in larval fish survival and subsequent recruitment. In: Lasker, R. (ed.) Marine fish larvae. Morphology, ecology, and relation to fisheries. University of Washington Press, Seattle, p. 79-87

Leggett, W. C., Frank, K. T., Carscadden, J. E. (1984). Meteorological and hydrographic regulation of year-class strength in capelin (Mallotus villosus). Can. J. Fish. Aquat. Sci. 41: 1193-1201

Lewis, R. M., Wilkens, E. P. H., Gordy, H. R. (1972). A description of young Atlantic menhaden, Brevoortia tyrannus, in the White Oak River estuary, North Carolina. Fish. Bull. U.S. 70: 115-118

Liu, W. G., Katsaros, K. B., Businger, J. A. (1979). Bulk parameterization of air-sea exchanges of heat and water vapor including the molecular constraints at the interface. J. Atmos. Sci. 36: 1722-1735

Lough, R. G. (1984). Larval fish trophodynamic studies on Georges Bank: sampling strategy and initial results. Flodevigen rapportser 1: 395-434
Maillet, G. L. (1988). Otolith increment growth patterns in Atlantic menhaden (Brevoortia tyrannus) larvae and their relation to meteorological and oceanographic variables. M. Sc. thesis, North Carolina State University, Raleigh

Maillet, G. L., Checkley, D. M. Jr (1990). Effects of starvation on the frequency of formation and width of growth increments in sagittae of laboratory-reared Atlantic menhaden (Brevoortia tyrannus) larvae. Fish. Bull. U.S. 88: 155-165

May, R. C. (1974). Larval mortality in marine fishes and the critical period concept. In: Blaxter, J. H. S. (ed. ) The early life history of fish. Springer-Verlag, Berlin, p. 3-19

Methot, R. D., Kramer, D. (1979). Growth of northern anchovy, Engraulis mordax, larvae in the sea. Fish. Bull. U.S. 77: $413-423$

Mosegaard, H., Svedang, H., Taberman, K. (1988). Uncoupling of somatic and otolith growth rates in Artic char (Salvelinus alpinus) as an effect of differences in temperature response. Can. J. Fish. Aquat. Sci. 45: 1514-1524

Mugiya, Y., Watabe, N., Yamada, J., Dean, J. M., Dunkelberger, D. G., Shimuzu, M. (1981). Diurnal rhythm in otolith formation in the goldfish, Carassius auratus. Comp. Biochem. Physiol. 68A: 659-662

Mullin, M. M., Brooks, E. R., Reid, F. M. H., Napp, J., Stewart, E. F. (1985). Vertical structure of nearshore plankton off southern California: a storm and a larval fish food web. Fish. Bull. U.S. 83: 151-170

Nelson, W., Ingham, M. C., Schaaf, W. E. (1977). Larval transport and year-class strength of Atlantic menhaden, Brevoortia tyrannus. Fish. Bull. U.S. 75: 23-42

Owen, R. W. (1980). Patterning of flow and organisms in the larval anchovy environment. In: Sharp, G. D. (ed. ) Workshop on the effects of environmental variation on survival of larval pelagic fishes. Intergovernmental Oceanographic Commission, Workshop Report No. 28. UNESCO, FAO, Rome, p. 167-200

Owen, R. W., Lo, N. C. H., Butler, J. L., Theilacker, G. H., Alvarino, A., Hunter, J. R., Watanabe, Y. (1989). Spawning and survival patterns of larval northern anchovy, Engraulis mordax, in contrasting environments - a site intensive study. Fish. Bull. U.S. 87: 673-688

Penney, R. W., Evans, G. T. (1985). Growth histories of larval redfish (Sebastes spp.) on an offshore Atlantic fishing bank determined by otolith increment analysis. Can. J. Fish. Aquat. Sci. 42: 1452-1464

Peterman, R. M., Bradford, M. J. (1987). Wind speed and mortality rate of a marine fish, the northern anchovy (Engraulis mordax). Science 235: 354-356

Powell, A. P., Phonlor, G. (1986). Early life history of Atlantic menhaden, Brevoortia tyrannus, and Gulf menhaden, B. patronus. Fish. Bull. U.S. 84: 991-995

Radtke, R. L. (1984). Cod fish otoliths: information storage structures. The propagation of cod Gadus morhua L. Flodevigen rapportser 1: 273-298

Rothschild, B. J., Osborn, T. R. (1988). Small-scale turbulence and plankton contact rates. J. Plankton Res. 10: 465-474

SAS Institute Inc. (1984). SAS/ETS user's guide, Version 5 edn. SAS Institute Inc., Cary, NC

Secor, D. H., Dean, J. M. (1989). Somatic growth effects on the otolith - fish size relationship in young pond-reared striped bass, Morone saxatilis. Can. J. Fish. Aquat. Sci. 46: 113-121

Shepherd, J. G., Pope, J. G., Cousens, R. D. (1984). Variations in fish stocks and hypotheses concerning their links with climate. Rapp. P.-v. Réun. Cons. int. Explor. Mer 185: 255-267

Simpson, J. J. (1987). Transport processes affecting the survival of pelagic fish stocks in the California Current. Am. 
Fish. Soc. Symp. 2: 39-60

Sundby, S., Fossum, P. (1990). Feeding conditions of Arctonorwegian cod larvae compared with the RothschildOsborn theory on small-scale turbulence and plankton contact rates. J. Plankton Res. 12: 1153-1162

Therriault, J. C., Lawrence, D. J., Platt, T. (1978). Spatial variability of plankton turnover in relation to physical processes in a coastal environment. Limnol. Oceanogr. 23: 900-911

Tilseth, S., Ellertsen, B. (1984). The detection and distribution of larval Arcto-Norwegian cod, Gadus morhua, food organisms by an in situ particle counter. Fish. Bull. U.S. 82: $141-156$

Volk, E. C., Wissmar, R. C., Simenstad, C. A., Eggers, D. M. (1984). Relationship between otolith microstructure and growth of juvenile chum salmon (Oncorhyynchus keta) under different prey rations. Can. J. Fish. Aquat. Sci. 41: $126-133$

This article was submitted to the editor
Warlen, S. M. (1988). Age and growth of larval Gulf menhaden, Brevoortia patronus, in the northern Gulf of Mexico. Fish. Bull, U.S, 86: 77-89

Wright, P. J., Metcalfe, N. B., Thorpe, J. E. (1990). Otolith and somatic growth rates in Atlantic salmon parr, Salmo salar L: evidence against uncoupling. J. Fish. Biol. 36: 241-249

Wroblewski, J. S., Richman, J. G. (1987). The non-linear response of plankton to wind mixing events - implications for survival of larval northern anchovy. J. Plankton Res. 9: $103-123$

Wroblewski, J. S., Richman, J. G., Mellor, G. L. (1989). Optimal wind conditions for the survival of larval northern anchovy, Engraulis mordax: a modeling investigation. Fish. Bull. U.S. 87: 387-395

Zweifel, J. R., Lasker, R. (1976). Prehatch and posthatch growth of fishes - a general model. Fish. Bull. U.S. 74: 609-621

Manuscript first received: April 26, 1991

Revised version accepted: November 21, 1991 